\title{
DE LA POSTCOMUNISM LA POSTMODERNITATE. CÂTEVA CONSIDERATIII PRIVIND PROVOCĂRILE MISIONARE DIN ORTODOXIA ROMÂNEASCĂ DUPĂ CĂDEREA COMUNISMULUI
}

\author{
David Pestroiu*
}

\begin{abstract}
During post-communist times, Romania has had the opportunity to employ its freedom to open new missionary vistas to denominations and mainly to the mainstream Orthdox Church. Reconstructing demolished churches, restoring religion to public school curriculum, developing Christian massmedia with TV and radio stations, news agency and church newspapers, establishing many Theology faculties and seminaries, publishing an immense body of Romanian and translated religious literature - all these aim to impart new missionary energy to the Romanian Orthodox Church, defining it as a dynamic Church, willing to renew its communication strategies, while staying faithful to its distinctive Tradition.

However concrete results, as far as religiosity of population is concerned, are far from our expectations. A new social paradigm postmodernity - fosters wrong, demiurgic attitudes, inspiring autarchical selfsufficiency and selfish individualism. How can we handle the challenges of postmodernity? To what extent can ecclesial mission prevent the desacralisation of human life, now overwhelmed by excessive material consumption? Which path should the Church take in such consumist, hedonistic world? These questions are as many starting points for topical theological research, whose importance and relevance lies precisely in the concreteness of the missionary message addressed to today's world.
\end{abstract}

Keywords: postcomunism, postmodernitate, ortodoxie, România, misiune.

* PhD, Associate Professor, "Justinian Patriarhul" Faculty of Orthodox Theology at University in Bucharest. 
Căderea comunismului a însemnat pentru Biserica Ortodoxă Română oportunitatea reluării activităţii sale misionare, oprimată vreme de 45 de ani. Este adevărat că statul comunist a recunoscut existența a 14 culte religioase, printre care şi Patriarhia Română, însă a impus restricții draconice faţă de manifestările de promovare a oricărui tip de credință religioasă. Reprezentanților acestor culte nu le era permisă decât stricta oficiere a ritualurilor proprii, cerută a se desfăşura, în mod obligatoriu, în atmosfera privată a lăcaşelor, fără nicio expunere publică. Predica şi cateheza, acțiunile filantropice, sociale sau culturale nu erau îngăduite. La instituțiile de învățământ ce pregăteau personalul clerical erau, de asemenea, interzise discipline teologice precum: misiologia, ascetica şi mistica, teologia fundamentală, formarea duhovnicească ${ }^{1}$. În cei 45 de ani de ateism promovat energic de la tribuna ideologică a partidului unic, mutațiile conştiințelor au produs erodarea percepției privind credința creştinortodoxă.

Sfârşitul anului 1989 a adus redeşteptarea spirituală a poporului român. Odată cu instaurarea, treptată, a democrației, s-a restabilit imaginea apartenenței la credința care a definit parcursul istoric al românilor. Revigorarea vieții religioase s-a concretizat printr-o nouă dimensiune misionară, concretizată în:

- Reorientarea parohiilor spre desfăşurarea activităţilor descrise prin sintagma "liturghia de după liturghie": filantropie, cateheză, acțiuni culturale şi misionare, care au readus Biserica

${ }^{1}$ Mulți clerici au fost prigoniți doar pentru îndrăzneala de a predica. Dintre aceștia, se remarcă Părintele Gheorghe Calciu - Dumitreasa, fost profesor la Seminarul Teologic din Bucureşti, care a încercat să transmită tinerilor mesajul credinței în fața ofensivei ateismului, în prelegerile rămase emblematice: $\square$ apte cuvinte către tineri (1978). Atât înainte, cât şi după acest an, a suferit tortura temnițelor comuniste, fiind eliberat doar după intervenția președintelui S. U. A. din acea vreme, Ronald Reagan, în 1984. Un an mai târziu a fost silit să părăsească țara, refugiindu-se în S. U. A., de unde a sprijinit în continuare misiunea ortodoxă prin predicile transmise constant de posturile de radio Europa Liberă şi Vocea Americii. 
Ortodoxă Română pe locul consacrat de istorie în definirea identitară a poporului român;

- Redeschiderea locaşurilor de cult închise de regimul comunist şi începerea lucrărilor de construcţie la noi biserici, mai ales în cartierele de blocuri ridicate în perioada totalitarismului;

- Inițierea şi consolidarea unor relații de conlucrare cu celelalte culte, considerate partenere ale statului în vederea asigurării păcii şi armoniei sociale;

- Reluarea prezenței orei de Religie în învățământul de stat, organizată pe principii confesionale, cu participarea cultelor recunoscute;

- Reprimirea facultăţilor de teologie ortodoxă, precum şi ale altor confesiuni, în cadrul universităților de stat, de unde fuseseră scoase, în mod samavolnic, de către regimul comunist ${ }^{2}$;

- Deschiderea unor noi dimensiuni de slujire misionară, prin prezența unor clerici consacrați pentru activități liturgice şi pastorale, în penitenciare, spitale, cimitire şi unităţi militare;

Principalele provocări ale postmodernității, care afectează în mod direct viaţa religioasă în România actuală, sunt următoarele:

1. Conturarea unei noi paradigme antropologice, autarhică şi individualistă. Omul trăieşte drama descrisă de J. F. Lyotard, cel ce a definit condiția postmodernă ca fiind ,incredulitatea arătată alcătuirilor meta-narative"3. Istoria, ca succesiune de evenimente ale umanității raportate la vectorul timp, nu mai prezintă importanță pentru cei ce trăiesc un prezent continuu al unui trai consumist. Este, de fapt, o ancorare în viața pământească materială, gândită ca o succesiune de evenimente derulate în manieră hedonistă. Veşnicia fericită în împărăția lui Dumnezeu nu mai este privită de

${ }^{2}$ Facultatea de Teologie Ortodoxă din București figurează între facultăţile fondatoare ale Universității din București, în urmă cu 150 de ani.

${ }^{3}$ Jean François Lyotard, The Postmodern Condition: a report on Knowledge, Translation from the French by Geoff Bennington and Brian Massumi, Foreword by Fredric Jameson, Minneapolis, University of Minnesota Press, 1984 , p. XXIV. 
aceştia ca un scop al existenței lor. Mai degrabă, se doreşte continuarea traiului materialist prin reîncarnări succesive, preluate pe firul sincretic propus de New Age, din religiile de proveniență orientală. Idolatrizarea sinelui constituie marea dramă socială a postmodernităţii. Este o ruptură abisală față de traiul comunitar şi solidaritatea agapică a creştinismului. Față de această provocare, Biserica Ortodoxă Română a intensificat activitatea de catehizare individuală, precum şi pastorația credincioşilor la Taina Spovedaniei.

2. $\mathrm{Nu}$ numai sinele este obiectivul noii idolatrii postmoderne. Există o multitudine de alți idoli ai momentului: munca şi ascensiunea profesională, familia sau anumiţi membri ai acesteia, banii şi agonisita materială, idealurile politice, economice sau sociale, ficțiuni din producții media sau din cinematografie, vedete din toate domeniile sau chiar sporturi - vorbindu-se tot mai des de „zeul fotbal", de pildă, iar despre stadioane ca ,temple ale fotbalului". Credința tradițională în Dumnezeu rămâne, de cele mai multe ori, la nivelul unei simple exprimări declarative (Crăciun şi Paşte transformate în evenimente mondene, cu relevanţă preponderent gastronomică, sau, mai nou, experimentate prin turism „exotic" sau celebrate „tinereşte" în cluburi şi discoteci; slujbele de botez, nuntă, înmormântare - privite doar ca exprimări folclorice, cu o prezență în continuă scădere a invitaților la ritualul religios). Cauza majoră a acestor stări de lucruri rezidă în conceperea lumii ca fiind autonomă şi, implicit, idolatrizarea ei, şi impunerea unui abis între transcendența lui Dumnezeu şi imanența lumii. Dacă nu vom înţelege, aşa cum ne arată Sfântul Grigorie Palama, isihastul athonit al veacului al XIV-lea, că Dumnezeu coboară în lume, pentru a o sfinți cu energiile sale necreate, ridicându-o la Sine ca trup mistic al Său, nu vom putea contracara idolatriile contemporane.

3. În plan doctrinar, se remarcă marginalizarea surselor autentice ale Revelației dumnezeieşti, Sfânta Scriptură şi Sfânta Tradiție. În privinţa Scripturii, se resimt presiunile postmodernitătiii, realizate prin intermediul unor canale mediatice cu audiență ridicată şi pretenții de ştiinţificitate, pentru modificarea canonului autentic al acesteia, prin includerea unor texte apocrife, de sorginte gnostică, 
distructive la adresa mesajului original, dar favorabile transmiterii noilor învățături postmoderne, care susțin, în principal, libertățile greşit înțelese, care relativizează păcatul şi erodează instituția familiei, celula de bază a societății. De asemenea, şi Tradiția este negată, fie prin regretabila confuzie cu datinile omeneşti, impregnate de ocultism, fie prin înlocuirea ei cu produse de import, străine spiritului autohton, dar foarte necesare avansării procesului de globalizare, care a depăşit de mult planul politico-economic, intervenindu-se acum în domeniul cultural-religios. Unele sărbători religioase ortodoxe sunt trecute într-un plan secundar al interesului public, în timp ce manifestările intens mediatizate ale „Halloween” sau „Valentine's Day” au devenit deja o obişnuință, inclusiv în şcoli. În plus, nu trebuie omisă pretenția unor mişcări religioase pentru promovarea conceptului de „revelație deschisă”, precum şi falsele învățături ale „noilor profeți” contemporani. Față de toate acestea, Ortodoxia Românească a rămas fidelă mărturisirii importanței Revelației divine, a fidelității faţă de textul sacru şi a păstrării valorilor perene ale Tradiției.

4. Tot în plan doctrinar, se remarcă reînvierea vechilor erezii, combătute la Sinoadele Ecumenice din primele veacuri creştine. Dogma trinitară este înțeleasă în mod subordinaționist, Persoana lui Iisus Hristos fiind redusă doar la simpla statură umană, iar Cea a Duhului Sfânt la o simplă forță sau energie. Accentuarea umanității lui Hristos prezintă o problematică aparte, din perspectiva noilor producții hiper-mediatizate ale postmodernității, atât cele ficționale (romanul şi filmul Codul lui da Vinci), cât şi cele pretins ştiințifice (documentarele Discovery privitoare la mormântul pierdut al lui Iisus Hristos). În ambele cazuri, se doreşte schimbarea imaginii mesianice a Fiului lui Dumnezeu şi distorsionarea chipului său divin, prin prezentarea unor false relatări, de sorginte gnostică, care-L consideră făptuitor al unor patimi trupeşti, iar la sfârşitul vieții, îngropat într-un mormânt comun. Față de aceste concepții, Biserica Ortodoxă Română continuă să predice învățătura privind persoana divino-umană a Mântuitorului Iisus Hristos, în forma aprobată de Sinodul Ecumenic de la Calcedon, din anul 551. 
Societatea postmodernă reprezintă un real ferment pentru cultivarea unor mentalităţi anti-creştine şi anti-religioase. Dacă în trecut ateismul se manifesta cu decența şi respectul fireşti unei bune relaționări în plan social, astăzi se constată un nedorit avânt al nihilismului, cu manifestări violente şi replici pe măsură ${ }^{4}$. A devenit o modă faptul de a batjocori ceea ce altul consideră a fi sacru, de a discredita valorile spirituale definitorii pentru spațiul cunoaşterii şi gândirii religioase. În România, mai multe ONG-uri cu număr infim de adepți, însă foarte gălăgioase, cumpără cu finanțări externe obscure spații mediatice ample, în care denigrează sistematic Biserica Ortodoxă Română şi pe slujitorii ei. Toma Pătraşcu, liderul Asociației Secular Umaniste din România, se deconspiră, afirmând că încă din 2011 a început o activitate de lobby împotriva organizării tradiționale a creştinismului românesc ${ }^{5}$. $\mathrm{Cu}$ toate acestea, Patriarhia Română şi-a manifestat în repetate rânduri disponibilitatea spre dialog, răspunzând în faţa urii cu infinită dragoste şi răbdare. Pericolul izbucnirii unor violențe religioase, pentru românii ortodocşi, este inexistent, din simplul motiv că aceştia au primit educația iubirii aproapelui.

6. Aşa cum corect arată Paul Lakeland, „postmodernitatea este întrepătrunderea dintre emancipare şi demonic" ". Avansarea noilor tehnologii aduce după sine creşterea, în egală măsură, a unui alt tip de luciferism. Copleşit de sisteme informatizate, gadgeturi, mijloace rapide de comunicare, sisteme audio-video sofisticate, omul contemporan se refugiază în cyberspațiu. Dar oare îşi va găsi aici echilibrul şi pacea interioară? Se vorbeşte din ce în ce mai mult de căsătorii virtuale şi chiar de spovedanii pe internet. Însă, la o analiză profundă, acest fenomen, necontrolat, poate conduce foarte uşor la demonism. O mulțime de

\footnotetext{
${ }^{4}$ A se vedea recentele escaladări conflictuale din Franța, unde atitudinea sfidătoare a jurnaliştilor Charlie Hebdo a determinat violenţe teroriste extreme. ${ }^{5}$ A se vedea http://m.hotnews.ro/stire/18901107, accesat la data de 23.01.2015.

${ }^{6}$ P. Lakeland, Postmodernity: Christian Identity in a Fragmented Age (Guides to Theological Inquiry Series), Minneapolis, Fortress Press, Minnesota, 1997. p. 89.
} 
capcane sunt întinse într-un spațiu ce necesită, mai întâi, o asanare din perspectiva discernământului creştin. $\square$ i aici Biserica este chemată să intervină. Mesajul ei, acelaşi de 2000 de ani, este o chemare la comuniune. Mântuirea nu se poate obține decât într-o relaţie de armonie perfectă cu Dumnezeu, semenii şi întreaga creație.

7. Mentalitatea postmodernă încurajează secularismul. Acesta este mult mai nociv decât ateismul, întrucât beneficiază de masca disimulatorie a falsei declarări a apartenenței religioase. În realitate, s-a încetățenit „believing without belonging”"7. Este mult mai comodă afilierea declarativă faţă de un sistem religios, precum şi criticarea lui din interior pentru că ar fi incapabil să se reformeze, decât practicarea asumată a unor reguli considerate retrograde şi restrictive. Este negată, deci, orice formă de religie instituționalizată. $\mathrm{Cu}$ toate acestea, Bisericile Tradiționale şi, în mod special, cea Ortodoxă, insistă asupra importanței păstrării formelor religiozității manifeste, menite să-l apropie pe om de Dumnezeu, să-i rostuiască viaţa în pace şi echilibru şi să-i ofere un sens al existenței: veşnicia cea fericită. Pentru cultivarea evlaviei şi păstrarea religiozității, Ortodoxia românească accentuează valoarea duhovniciei, a ascetismului de tip isihast, care ilustrează puterea rugăciunii drept călăuză a vieții umane. Mânăstirile sunt adevărate oaze ale păstrării şi dezvoltării unui stil de viaţă care, deşi rupt de lume, este ancorat în realitățile lumii, oferind remedii spirituale în fața provocărilor secularismului. De asemenea, pătrunderea duhului rugăciunii şi cântării liturgice în casele oamenilor, în maşini sau la locul de muncă, prin stațiile Radio şi TV Trinitas ale B. O. R., păstrează vie o stare religioasă de pietate, reamintind că scopul şi rolul vieții umane este apropierea de Dumnezeu.

8. Influențele seculare se răsfrâng, din păcate, şi asupra educației religioase. După aproape 50 de ani de comunism, studiul religiei a fost reintrodus în şcolile de stat din România, la toate

Expresia a consacrat chiar şi o cercetare aparte: Grace Davie, Religion in Britain Since 1945: Believing Without Belonging, Blackwell, Oxford, Institute of Contemporary British History, 1995. 
nivelurile. A fost o reparaţie morală, dar, totodată, o şansă pentru a oferi copiilor şi tinerilor accesul la valorile credinței. Treptat, tot mai multe presiuni caută să pună capăt acestui proces educațional. S-a obiectat, în mod cu totul fals, că predarea religiei de către persoane aparținând unor anumite culte ar transforma această disciplină într-o materie confesională, cerută a se studia în locaşurile de cult proprii, şi nu în şcoli. Aşa-zisa, ,îndoctrinare" a fost combătută prin exemplificarea programei analitice şi a manualelor folosite, în care toate religiile şi cultele sunt prezentate într-o manieră tolerantă. $\mathrm{Nu}$ a fost de ajuns. S-a solicitat să se studieze o materie-hibrid, intitulată: „istoria religiilor” sau „ştiința religiei”, în care, de fapt, să nu se facă o pledoarie față de credința religioasă, ci o critică vehementă la adresa acesteia, indiferent sub ce formă ar exista. Aceste voci sunt deja o constantă în peisajul mediatic românesc, fiind extrem de mediatizate, într-o formă vădit manipulatorie. Recent, au reuşit o modificare legislativă importantă, care vizează creşterea volumului birocratic al demersurilor privind studiul religiei, dar şi delimitarea acesteia de celelalte discipline. Asistăm la o adevărată procedură de „eroziune", având drept scop schimbarea mentalității colective, prin atragerea cât mai multor contestatari - în cea mai mare parte persoane influențabile, fără capacitatea argumentării poziționării lor față de subiectul în cauză. În acest caz, Patriarhia Română a căutat, prin toate mijloacele specifice, să-şi facă recunoscută vocea, trăgând semnale de alarmă asupra pericolelor la care societatea secularizată se expune. S-a reuşit perfecționarea manualelor de religie şi a tematicii prevăzută în programa analitică şi s-a căutat o selecție atentă a cadrelor implicate în procesul de predare, pentru a îndeplini această activitate cu pasiune şi zel misionar. Prin dialoguri specifice, inițiate de Patriarhia Română, toate cultele recunoscute din România, cu excepția Martorilor lui Iehova, s-au unit în demersul privind asigurarea învățământului teologic în şcoli, prin predarea Religiei, drept o şansă pentru viitor.

9. Intr-o lume globalizată, în care granițele dispar, încurajându-se piața liberă economico-financiară, s-a ajuns rapid să 
se vorbească despre un „supermarket cultural şi religios". Proliferarea noilor mişcări religioase explică apetența omului postmodern spre o religiozitate de conveniență, care să-i justifice aspirațiile hedoniste şi consumiste. Aşa se explică avântul curentelor advento-mileniste, care propun drept soluții mântuitoare paradisuri pământeşti milenariste, care să prelungească starea concupiscentă experimentată în viața trupească. Pentru Martorii lui Iehova, de pildă, fericirea eshatologică a împărăției cerurilor, atât de des amintită de Iisus Hristos în predicile sale, este restricționată sever la un număr de fix 144.000 de „aleşi”. Restul milioanelor de adepți îşi propun să populeze „noul pământ”, un loc în care atracția principală, potrivit inspiratei exprimări a Barbarei Harrison, va fi însuşi traiul de zi cu zi, care „va arăta exact ca un nesfârşit picnic în Kansas - sau un texan barbecue"

10. Confuzia între spiritualitatea ortodoxă şi ocultismul păgân, datinile folclorice, superstițiile şi magia demonică, divinaţiile şi ghicitoria de orice fel, inclusiv horoscoapele şi astrogramele, este tipică pentru a ilustra consecințele nefaste ale New Age-ului în România. Omul postmodern este victimă sigură: trăieşte drama acestei confuzii, în timp ce declamă, autoritar, că nu crede în nimic care să nu poată fi experimentat. S-a creat o adevărată isterie în jurul loteriilor, pariurilor, tombolelor etc. - toate aducătoare de câştig nemuncit. Riscurile, numite adesea ,provocări” se întâlnesc la tot pasul: în afaceri, la burse, ba chiar în practicarea unor sporturi şi distracții „extreme”. Mentalitatea ce stă în spatele acestor practici relevă, de fapt, pe de o parte, individualismul despre care am vorbit deja (credința că un eventual câştig este perfect cuvenit, fără a avea vreun resentiment faţă de numeroşii perdanți), iar pe de altă parte,

${ }^{8}$ World Council of Churches - Mission and Evangelism, Believing without belonging? In search of new paradigms of church and mission in secularised and postmodern contexts, Consultation in Breklum, Northern Germany, 2002, http://www.oikoumene.org/en/resources/documents/commissions/mission-andevangelism/consultation-on-mission-in-secularised-and-postmodern-contexts.

${ }^{9}$ Barbara Grizzuti Harrison, Visions of Glory: A History and a Memory of Jehovah's Witnesses, New York, Simon \& Schuster, 1978. 
nihilismul, desconsiderarea sinelui, a familiei, chiar a propriei vieți (concepția că fără risc, nu există câştig, precum şi aceea că viața trebuie trăită la intensitate maximă, ea având exclusiv o coordonată trupească şi pământească).

Față de provocările postmodernității, ortodoxia românească răspunde prin păstrarea statorniciei creştinismului tradiţional, cu notele specific naționale, dar ancorată viguros în realitățile prezentului. Toate mijloacele pe care tehnicile de comunicare de ultimă oră ni le pun la dispoziție trebuie valorificate spre câştigarea unor noi resurse misionare care să contracareze, pe de o parte, himerele hedonismului contemporan, iar pe de altă parte să confere propovăduitorilor şansa unei noi deschideri spre reîncreştinarea unei societăţi în derivă şi, mai ales, a tineretului debusolat de ispita consumismului.

\section{Bibliografie:}

1. Davie, Grace, Religion in Britain Since 1945: Believing Without Belonging, Blackwell, Oxford, Institute of Contemporary British History, 1995.

2. Grizzuti Harrison, Barbara, Visions of Glory: A History and a Memory of Jehovah's Witnesses, New York, Simon \& Schuster, 1978.

3. Lakeland, Paul, Postmodernity: Christian Identity in a Fragmented Age (Guides to Theological Inquiry Series), Minnesota, Fortress Press, Minneapolis, 1997.

4. Lyotard, Jean François, The Postmodern Condition: a report on Knowledge, Translation from the French by Geoff Bennington and Brian Massumi, Foreword by Fredric Jameson, Minneapolis, University of Minnesota Press, 1984.

5. Pestroiu, David, Religious Dialogue in Postmodernity. Necessity, chanches, perspectives, conferință susținută la Simpozionul internațional din 4-6 mai 2009, organizat de Facultatea de Teologie Ortodoxă a Universității „1 Decembrie 1918” din Alba Iulia, publicată în volumul: „Libertate și responsabilitate. Inițiative şi limite în dialogul religios", Alba Iulia, Editura Reîntregirea, 2009.

6. Idem, Misiunea Bisericii Ortodoxe in postmodernitate, conferință susținută la Simpozionul internațional: Biserică şi misiune în contextul interculturalitătuii, organizat în cadrul Facultății de Teologie Ortodoxă a Universității „Ovidius” 
din Constanţa (2 iulie 2008), publicată în: „Theologia Pontica”, revista Centrului de Cercetări Teologice Interculturale și Ecumenice „Sf. Ioan Cassian”, Facultatea de Teologie Ortodoxă a Universității „Ovidius”, Constanța, Anul II (2009), nr. 1, ianuarie-martie.

7. World Council of Churches - Mission and Evangelism, Believing without belonging? In search of new paradigms of church and mission in secularised and postmodern contexts, Consultation in Breklum, Northern Germany, 2002, http://www.oikoumene.org/en/resources/documents/commissions/mission-andevangelism/consultation-on-mission-in-secularised-and-postmodern-contexts. 8. http://m.hotnews.ro/stire/18901107, accesat la data de 23. 01. 2015. 